UDC 811.111'42

DOI https://doi.org/10.32841/2409-1154.2021.48-1.17

\author{
Zaitseva M. O., \\ PhD in Philology, Associate Professor, \\ Associate Professor at the Department of Foreign Languages № 2 \\ Yaroslav Mudryi National Law University
}

\title{
EVOLUTION OF THE EMOTIVE CODE OF ENGLISH COURT DISCOURSE
}

Summary. The article is devoted to the problem of text emotivity, which has become an impetus for the formation of a new linguistic direction - emotiology that allowed to bring the category of emotivity to the cognitive and communicative level of its understanding. The new level of understanding of this problem has drawn attention to the cognitive and communicative problems involving identifying the expressive potential of language capable of reflecting the emotional state of the speaker; and determining the role of text emotivity in achieving pragmatic goals of communication. The article focuses on the fact that the degree of the text emotivity gives rise to addressee's reactions along with the formation of a special emotional state, in which the communicative strategy of the sender of the speech is fully realised and eventually the perlocutive effect is achieved. In view of the above, the present study has been carried out at the intersection of several scientific and linguistic paradigms: communicative, cognitive, pragmatic and linguistics. The logic of the development of these branches of modern linguistic science has made this research relevant.

Lack of research of the phenomenon of the emotive code, the narrowness of the research material and the absence of works on the transformation of the emotive code have determined the goal of this paper, which is to trace the evolution of the emotive code of texts of English court discourse.

Because of this, the following tasks are proposed in the paper: examining the formation of the term "emotivity", reviewing the leading scholars' works dealing with emotivity, identifying language means that create the emotive code of texts of court discourse, determining the process of changes in the expression of language means that create emotivity in texts of English court discourse.

Based on the analysis of the factual material, we have found that there has been an evolution in the emotive code of texts of English court discourse. At the beginning of the twentieth century, prosecutors' speeches were restrained and implicitly emotive; at the beginning of the twenty-first century they became more expressive and explicitly emotive.

The practical value of the paper is in providing the possibility of using its provisions and conclusions, the factual material in the study of communicative science, psycholinguistics, discourse analysis, in the practice of translation, linguistics and area studies, in the course of legal writing, oratory.

The theoretical value of the paper is in the fact that the article for the first time presents a comparative review of the degree of expression and the process of changing the emotional code of texts of English court discourse of the early twentieth century and the beginning of the twenty-first century.

Key words: emotivity, emotive code, court discourse, cognitive and communicative level, implicit emotivity, explicit emotivity.
Introduction. The processes taking place in society affect all kinds and forms of human activities, including communicative one. All of them are reflected in the text, which is considered not as an abstract philological phenomenon, but as a social phenomenon. A number of certain factors determines the parameters of the text such as extra-linguistic communicative and cognitive task, the situation of the act of communication, the personal characteristics of the addressee and the recipient [1]. Therefore, it is quite natural that interest in the text is increasing not only in linguistics, but also in other scientific disciplines: psychology, political science, conflictology, rhetoric, argumentation theory, etc. However, despite the fact that the problems of the text have been developed for a long time and in different aspects, there are still issues that are not fully disclosed, such as the problem of definition of discourse and its typology. In addition, there are new questions that need to be solved. Such a problem, as V.A. Maslova rightly points out, is the problem of text emotivity [1], which prompted the formation of a new linguistic trend - emotiology, "which allowed us to bring the category of emotionality to a new level of theoretical understanding" [1, p. 254], to the cognitive and communicative level. Such a turn let us pay attention to the solution of cognitive-communicative tasks - to reveal to what extent the expressive potential of language is able to reflect our emotional state and what role the phenomenon of emotivity of the text plays "...in achieving those pragmatic goals of communication for which in general...any texts are created" [2, p. 148]. The emotivity of the text determines the recipient's response, the formation of the recipient's particular emotional state. It contributes to the maximum realisation of the communicative strategy of the sender of the speech, thus achieving a perlocutive effect. With this in mind, we have carried out the research at the intersection of several scientific and linguistic paradigms: communicative, cognitive, pragmatic and linguocultural. The logic of the development of these areas of modern linguistic science has determined the relevance of this study.

Recent researches analysis. Having analysed many linguistic studies on the problems of textual emotionality, we have come to the conclusion that, as a rule, the authors usually examine specific emotive linguistic means and their organisation in the semantic space of a particular text. This fact is manifested in the works of both linguistics masters $[3,4,5]$ and modern scholars $[6,7,8]$. However, for the most part, both long been known and contemporary studies have most often focused on fiction texts, less often on scientific and political texts. On the other hand, as researches show, even a text with lots of emotive means does not always evoke «an adequate emotional effect, leaving the addressee indifferent, and sometimes leads to the emergence of emotions opposite to those planned» [2], so the presence of emotive means per se is not yet a guarantee of achieving a perlocutive effect. 
Obviously, there is the so-called an emotive code of the text (V.I. Shakhovsky's term), which is represented by the totality of all linguistic means involved in the text and organised in such a way as to convey the meaning of the statement to the recipient and ensure maximum emotional impact on the recipient of information.

Even a brief review of the works dedicated to this issue as well as the extent to which the issue has been studied gives grounds for asserting that this aspect has not been fully researched, firstly, and secondly, it is somewhat narrowly examined as far as the material of the research is concerned.

Thus, the aim of this paper is to identify how the emotive code of texts of English court discourse has evolved. In order to achieve this goal, the following tasks are to be solved:

1) to clarify the terminological apparatus involved in the article;

2) to establish the language means expressing emotiveness in texts of American court discourse of the early twentieth century;

3 ) to establish the language means expressing emotiveness in texts of American court discourse of the early twenty-first century;

4) to find out the evolution, if any, of these language means.

\section{Results and discussion.}

The aim, objectives and specificity of the material determined the choice of methods of analysis.

At the stage of terminological grounding the main methods are comparison (comparing the views of different scholars, directions of problem analysis, etc.), classification (identifying linguistic means), generalisation (summarising information), argumentation (in support of its position).

In our choice of approaches to the analysis we were guided by the contemporary scientific paradigms: cognitive linguistics, pragmatic linguistics, speech communication theory, lexicosemantic analysis methods. Elements of cognitive analysis helped to identify the dependence of court discourse on social conditions.

The factual material of the study was authentic materials (texts of speeches of defense lawyers) of five famous American trials: The Triangle Factory Fire (1911), Louise Woodward Trial (1978), Amadou Diallo Trial (1999-2000), M. Jackson suspected paedophilia Trial (2005), Steven Allan Avery Trial (2007).

Emotivity in speech,as sketched above, is realised with the help of particular linguistic means, that is, emotives, which are present at all language levels and form an emotive language code.

The emotive code of language correlates the mental state of interlocutors with the corresponding linguistic means. It may be added at this point that emotives in speech have two main functions: 1) emotional expression and 2) emotional impact. Although, in our opinion, this distinction can be considered rather conditional, as practically they are closely intertwined. However, it should be noted that in court discourse, the second function - the function of targeting the addressees - pursuing the pragmatic intention of influencing the recipient in the right direction in order to make them do something and to evoke certain feelings in them, plays a more significant role.

Emotives are primarily represented at the lexical level. Thus, three groups of lexical emotives are distinguished: 1) lexicon denoting emotions; 2) lexicon expressing emotions; 3) lexicon describing emotions [6]. Yet, there is no detailed understanding about emotionally neutral lexical means that acquire emotive connotations in the context. We would like to stress that it can be claimed as the first working hypothesis of this paper. Emotional meaning can be expressed by emotionally neutral vocabulary, as «an emotive load can be present in any word said to the communicant, as it is related to the individual linguistic consciousness" [4].

In addition, the emotive load, as mentioned above, can be determined by the context in which linguistic means either express their emotive potential or acquire it at the expense of, for example, intonation. According to V. Shakhovsky's comment, intonation helps to understand the emotional meaning of a word and can even "give emotive words the opposite meaning" [5]. In his works the scholar distinguishes between such notions as "text emotivity" and "emotive type of text". The former implies "a certain degree of text emotivity, emotive inclusions", while an emotive text is "a kind of 'building' in which all the 'floors' of language emotionality are represented and all channels..." [5].

Each discourse and each text as a form of discourse realisation has its own emotional code, which we understand as a set and organisation of linguistic and stylistic means, reflecting the modality and tone of the discourse and text, their emotional impact on the addressees. It should be emphasised that scholars often refer to such means as linguistic means, reflecting the author's emotional attitude to the events described. However, the parties in court, trying to remain impartial, as required by the ritual and ceremonial nature of the process, do not show their emotional attitude, but aim primarily to strengthen the so-called pragmatic charge of the text, which we put forward as a second working hypothesis.

The author of a text, in our opinion, must have emotional competence, that is, the ability to use and organise a variety of linguistic and stylistic means in order to influence the recipients and thereby achieve his or her illocutive goal. The arguer appeals, if it is possible to say so, to the higher, meaningful emotions, the emotional intelligence. These higher emotions are linked to personal, socially significant values. The ability to experience such emotions is strongly associated with emotional intelligence. In their research "Emotional intelligence" in (1990) P. Salovey and J. Mayer defined emotional intelligence as "ability to monitor one's own and other's feelings and emotions, to discriminate among them, and to use this information to guide one's thinking and action" [9, p. 189]. Obviously, the higher the level of emotional intelligence, the greater the ability of the speaker to evoke and control the necessary emotions; and the greater the ability of the recipient, at whom the speech is aimed, to manage their emotions, to recognise the emotional impact of the arguer. Undoubtedly, the first thing that emotional intelligence affects is the ability to recognise the emotions of others and to draw conclusions from them. People with high EQ are more likely to work on rhetorical techniques or already have a good command of persuasive techniques. They are able to verbally indicate priorities and convince listeners of the benefits of said priorities.

In the case of The Triangle Factory Fire (1911), for example, the trial ends with the prosecutor's closing argument. Mr Bostwick emphasises the importance of the jury's verdict on the one hand, and highlights their common sense and good judgment on the other:

"You are chosen because you are believed to be eminently fit to apply the commonsense that you apply in the important daily matters in your business life. And when you come to determine the facts in a case you do not cease to be business men, you do not cease to be commonsense men; you are still those men of the community, exercising that same kind of commonsense judgment, and if you would act upon it in your everyday affairs, in the weighty affairs of your business, you should so act in this case, and that is what is meant by the conviction of a reasonable doubt". 
Note that the words that are initially positively emotive here are: eminently, important, weight. However, the following word combinations acquire a strong pragmatic charge and a positive emotive colouring in the context: apply the commonsense, in your business life in your business men, commonsense men, men of the community, commonsense judgment.

The arguer draws attention to the importance of everyday activities of jurors ("important daily matters in your business life", "weighty affairs of your business"). Simultaneously, he draws an analogy between their activity and the course of the trial, expanding their scope of activity and, consequently, the scope of attention. The created positive effect increases the range of careful selection and scrutiny of the facts by enthusiastic and value-filled recipients, selected as jurors, who believe that they are highly capable of applying their common sense:

"You are chosen because you are believed to be eminently fit to apply the commonsense".

Further, the positive emotions created, due to their mechanism of action, draw the recipients' attention to particular rather than abstract images:

"He referred to the fact that Dora Tiger had made a statement to the District Attorney's office. An error - no doubt, again, by inadvertence.

He said that none of the witnesses had said that Mr. Brown had opened that door with a key. Another error - it is not a fact".

The positive emotional background created in this example establishes a so-called informational focus, which is expressed in the fact that the honour and responsibility entrusted to worthy members of society to pass judgment on the guilt/ innocence of the defendants obliges them not to be distracted by secondary details, but to focus on the key points of the case. The concentration of attention leads the recipients to focus on the function of dignity for the judge, and civic duty - for the jury, to strive to present the picture as a whole, to rise above the level of the particular situation: "a positive mood, by signaling that a situation is benign, might allow people to step back and take in the big picture. As a consequence, a positive mood might increase abstract construal and the adoption of abstract, future goals" [10]. Significantly, the stage of establishing a positive emotional background is a kind of ceremonial step in every trial.

Appealing to a sense of self-importance and exclusivity on the one hand, and a sense of duty on the other, to create a positive background has been an inherent characteristic of prosecutorial discourse. Increasingly, however, prosecution representatives have recently avoided the standard approach to presenting information by appealing to a high sense of value in life, shifting the focus of their speeches. However "just" the defendant's actions may have been (this sense of "false justice", incidentally, is often appealed to by lawyers), but life is the ultimate and absolute value for a democratic society. This emotion serves as a catalyst, facilitating an appeal to phronesis, practical wisdom, when the focus of the judge and jury's attention is turned to their discharge of a high duty.

In the case of Louise Woodward Trial (1978) the prosecutor proclaims the value of every human life, the deprivation of which, through the actions of whoever is, is called a murder:

"We are not saying, that the defendant woke up on February 4th specifically intending to kill Matthew Eappen. What we're saying is that on February 4th, the defendant, in a frustrated, resentful, unhappy attitude, slammed the baby into a hard object and shook him, causing his death - actions that anyone would know would result in death. In this commonwealth, that is murder".

To be sure, we stress the presence of explicit language means that express the speaker's attitude towards the defendant: a frustrated, resentful, unhappy attitude.

As in the similarly high-profile case of the 1999-2000 Amadou Diallo Trial, where the prosecutor is claiming the right to life of any person:

"In the 1990s in Bronx County, in Albany County, or anywhere else a human being should have been able to stand in the vestibule of his own home and not be shot to death, especially when those doing the shooting are police officers sworn to protect innocent people".

Furthermore, in this trial, the prosecutor particularly emphasises that those who are supposed to protect him took the young man's life.

The 2007 Steven Allan Avery case is also worth mentioning:

"On Monday, October 31st, 2005, beginning 14 at approximately 2:45 p.m., the State intends to prove to you that the defendant restrained, murdered, and mutilated a 25 year old photographer named Teresa Halbach... We can't prove the why in a case like this. That's called motive, the reason behind the killing; what was in Mr. Avery's mind when he decided to kill this lovely young woman".

The prosecutor uses emotionally loaded language means: restrained, murdered, and mutilated.

A careful examination of the court documents helped to establish that in non-homicide cases, the prosecution appeals to other types of emotions, making emotional connections with other participants in the proceedings. For example, in the case of M. Jackson suspected pedophilia Trial:

"... the child had no father in his life, and had had no father in his life for over a year, because of the separation and divorce of the parents, and the fact that there was a court restraining order prohibiting the father from seeing the children. He exploited this paternal relationship and created another relationship with the child as a surrogate father...his admitted practice and longstanding custom and habit of sharing his bedroom, and his bed, with young boys".

The prosecutor creates a certain emotional state of the recipients, regarding them as members of a social group with traditional views on the family model, on the role of the father in the family. Appealing to the above conventional views contribute to the emergence of solidarity within the group. To do this he uses emotionally neutral language means, but places them in a setting where they receive a powerful pragmatic charge, becoming obviously emotive and conveying not only the recipient's attitude but also his emotions in relation to the defendant in the given legal case.

Conclusions and perspectives. A thorough comparative analysis of early twentieth and twenty-first century trials in terms of the emotive nature of judicial discourse has led us to the conclusion that there has been an evolution in the emotive code of texts of English court discourse. At the beginning of the twentieth century, prosecutors' speeches were restrained and implicitly emotive, while at the beginning of the twenty-first century they became expressive and explicitly emotive.

Implicit emotivity implies that emotionally neutral linguistic means acquire emotive connotations in the context. The implicit emotivity implies the use of initially expressively marked linguistic means. Thus, it is possible to talk about a change in the emotive code of texts of English court discourse: from implicitly emotive to explicitly emotive. It is due to, in particular, by cultural, that social, 
political changes. We find ourselves in full agreement with Herbert Marcuse who rightly pointed out that any "...linguistic analysis... carries an extralinguistic commitment" [11, p. 37]. Therefore, it is impossible to adequately characterise language means without taking into account the speaker's intention, the extralinguistic situation, the competence of the speaker, the level of linguistic and intellectual readiness of the listener to perceive the speaker's speech.

Being limited by the scope of the article, we could not fully cover all the issues of interest related to the problem of the emotional code of the text. With this in mind, we would like to point out that the study is promising from the point of view of such points as the degree of expression of the emotional code of texts of the advocate court discourse; which linguistic means, apart from lexical means, implement the category of emotivity of texts.

\section{References:}

1. Маслова В.А. Когнитивная лингвистика. Минск : ТетраСистемс, 2008. $272 \mathrm{c}$.

2. Маслова В.А. Коммуникативный подход к проблеме эмотивности текста. Коммуникативные аспекты значения. Волгоград, 1990. C. $148-156$.

3. Телия В.Н. Коннотативный аспект семантики номинативных единиц. Москва : Наука. $141 \mathrm{c.}$

4. Шаховский В.И. Лингвистическая теория эмоций. Москва : Гнозис, 2008. 416 с.

5. Шаховский В.И. Эмоции: долингвистика, лингвистика, лингвокультурология. Москва : ЛИБРОКОМ, 2010. 128 с.

6. Филимонова О.Е. Категория эмотивность в английском тексте (когнитивные и эмотивные аспекты): дисс. ... д-ра филол.наук. Санкт-Петербург, 2001. 382 с.

7. Чайковська Є.Ю. Поняття «емотивність» та «експресивність»у мові науки. Лінгвістика ХХІ століття: нові дослідження і перспективи. Київ : Логос, 2012. С. 279-287.

8. Свідер І.А. Основні особливості емотивного тексту. Наукові праці Кам'янець-Подільського наиіонального університету імені Івана Огієнка. Філологічні науки. 2013. Вип. 33. С. 275-278.

9. Salovey P., Mayer J. D. Emotional intelligence. Imagination, Cognition, and Personality, 9, 1990. P. 185-211.

10. Labroo A., Patrick V. Psychological Distancing: Why Happiness Helps You See the Big Picture. Journal of Consumer Research. 35, 2009. P. 800-809.

11. Маркузе, Г. Одномерный человек. Москва: 'REFL - Book', 1994. $368 \mathrm{c}$.

Зайцева М. О. Еволюція емотивного коду англійського судового дискурсу

Анотація. Статтю присвячено проблемі емотивності тексту, яка стала поштовхом для формування нового лінгві- стичного напряму - емотіології, що дозволило вивести категорію емотивності на новий когнітивно-комунікативний рівень іiї осмислення. Встановлено, що новий рівень осмислення цієї проблеми привернув увагу до вирішення когнітивно-комунікативних завдань, які полягають у виявленні виразного потенціалу мови, здатного відобразити емоційний стан мовця, у визначенні ролі емотивності тексту, в досягненні прагматичних цілей комунікації. У статті акцентується увага на тому, що ступінь емотивності тексту зумовлює виникнення певних реакцій у адресата, формування особливого емоційного стану, за якого максимально реалізується комунікативна стратегія адресанта, що сприяє досягненню перлокутивного ефекта. 3 урахуванням вищевикладеного наше дослідження виконано на перетині кількох науково-лінгвістичних парадигм: комунікативної, когнітивної, прагматичної і лінгвокультурологічної. Логіка розвитку цих напрямів сучасної лінгвістичної науки зумовила актуальність цього дослідження.

Недостатній ступінь вивченості феномену емотивного коду, вузькоспрямованість матеріалу дослідження і відсутність робіт з дослідження трансформації емотивного коду детермінували висування мети цієї роботи, яка полягає в тому, щоб простежити характер еволюції емотивного коду текстів англійського судового дискурсу.

3 урахуванням вищесказаного в статті висунуті наступні завдання: розглянути процес становлення терміну «емотивність», охарактеризувати погляди провідних вчених, що займалися проблемою емотивності, виокремити мовні засоби, що створюють емотивний код текстів судового дискурсу, визначити зміни в вираженості мовних засобів, що створюють емотивність текстів англійського судового дискурсу.

У результаті аналізу фактичного матеріалу встановлено, що сталася певна еволюція емотивного коду текстів англійського судового дискурсу: на початку двадцятого століття промови обвинувачів були стриманими та імпліцитно емотивними, а на початку двадцять першого століття вони стали експресивними та експліцитно емотивними.

Практична значущість дослідження полягає в можливості використання його положень та висновків, фактичного матеріалу під час вивчення комунікативістики, психолінгвістики, дискурсивного аналізу, в практиці перекладу, лінгвокраїнознавства, в курсі юридичного письма, ораторського мистецтва.

Теоретична значущість роботи полягає в тому, що був вперше проведений порівняльний огляд ступеню вираженості емотивного коду та його трансформації на матеріалі текстів англійського судового дискурсу XX-XXI століття.

Ключові слова: емотивність, емотивний код, судовий дискурс, когнітивно-комунікативний рівень, імпліцитна емотивність, експліцитна емотивність. 